\title{
5. Women in Australian politics: Mothers only need apply
}

\begin{abstract}
When Julia Gillard considered running for the leadership of the Australian Labor Party in early 2005, her political enemies immediately raised three reasons for opposing her: she is female, single and without children. These criticisms prompted a flurry of discussion in the media about the relevance of a person's family situation to their ability to work effectively in politics. This article examines the treatment of female politicians by the press over the more than 80 years since the first woman appeared in any Australian parliament. It finds that there continues to be pressure on women to continue in the traditional roles of wife and mother, while more recently, female politicians have had to contend with an extra layer of coverage concentrating on their sexual attributes.
\end{abstract}

\section{CATHY JENKINS}

Griffith University, Queensland

\section{Introduction}

I N JANUARY 2005 the Australian Labor Party was in the throes of electing a new leader. One of those considering running to replace outgoing leader Mark Latham was Julia Gillard, a frontbencher who had proved her mettle in the shadow portfolios of immigration, indigenous affairs and health. But there were perceived problems. Gillard is female, single and child free, and her political enemies wasted no time in using these attributes as weapons against her. Many media outlets were prepared to jump on the single-and-child-free issue, with help from their political sources. 'The relationship between sources and journalists resembles a dance, for sources seek access to journalists, and journalists seek access to sources, but more often than not, sources do the leading' (Gans 1979, p. 116). However, some media 
commentators needed no encouragement from sources to ponder on whether Gillard's home life was appropriate for a party leader. This paper examines the pressure on female politicians to fulfil the roles of wife and mother in order to be accepted in public life. It will take an historical overview of press concentration on traditional female roles, and how this concentration has evolved since women started entering Australia's parliaments.

Henderson (1999) argues that female politicians are routinely described according to their dress and appearance, while the media also concentrate heavily on the housewife/mother aspects of their lives, while Braden (1996) argues that this concentration on women's appearance and relationships can diminish their stature as legislators. However, it must be added some female politicians have fostered this softer, more caring image as a means of making themselves more attractive to the electorate (Lake, 1994), which has only helped to reinforce the media's view of women's traditional roles and attributes.

Van Acker (1999) points out that the media focus on a female politician's family life while largely ignoring her political activities, while Baird (2004, p. 87) argues that in politics, women have been and are still at the centre of the debate about combining parenthood with career. 'Men still work, are assumed to work, and male politicians are not challenged about their responsibilities, even when they have babies or toddlers.' This determination to see women continue in their housewife-and-mother roles has not only been a continuing theme in press coverage of female politicians in Australia, but has also become part of the cut and thrust of political life.

\section{Historical overview}

When Edith Cowan was elected to Western Australia's Parliament in 1921, there was some positive reaction to the first woman elected anywhere in the nation. However, there was also concern that her achievement might tempt other women away from their natural roles in life. A newspaper editorial made a comment that would have its echoes in the coverage of Gillard some 84 years later.

\footnotetext{
A Parliament composed wholly or mainly of woman politicians is not a prospect to be regarded with enthusiasm. Were political office to become the ambition of the fair sex, and were standing for Parliament to become the latest craze of fashion, there would be many dreary and
} 


\section{CONTEMPORARY GENDER ISSUES}

neglected homes throughout the country sacrificed on the altar of political ambition (Editorial, The Age, March 15, 1921, p.6).

The Bulletin was not so worried, but pondered rather irreverently on the changes that Cowan would bring to the Chamber. In a series of cartoons covering an entire page, she was portrayed as scrubbing the clerk's table and saying 'Bless my soul, whatever did you do before securing a decent housekeeper?' There were other cartoons featuring her with a mop and bucket, a broom, and a washtub and board, all in front of bemused male MPs in the Chamber. The caption at the bottom of the page read "THE NEW "HOUSE" WIFE' (March 31, 1921, p. 13).

When the first two women to enter federal Parliament were elected in 1943, one newspaper apparently did not consider that either of them would be unmarried. 'It is possible that Mrs Dorothy Tangney who is one of the Labor Senate candidates in West Australia, may also be elected' (The Age August 23, 1943, p. 1). The mistaken honorific in that sentence indicates a presumption that a woman of her age would be married. Tangney was single and of course childless when she entered Parliament at the age of 32, but the papers of the day still managed to give her a maternal air while also stressing the motherly role of new MLA, Dame Enid Lyons. The Courier-Mail featured two front page pictures of the pair. One showed Lyons' adult daughter adjusting the chain of her mother's gold parliamentary pass, while the other featured Tangney seated at her office desk in Canberra. The caption concluded 'among 500 messages of congratulation awaiting her attention were 100 from West Australian children' (September 23, 1943, p. 1). The Advertiser also reported that Tangney had received a telegram from her nephew, who was based in Darwin with the RAAF, asking for a fruitcake. The reporter wrote: '.. the fruit cake, she assured me, will soon be on its way' (September 25, 1943, p. 5). This was a reassuring set of pictures for society in general: one woman MP was still a mother, while the other was depicted as a 'de facto' mother to 100 children plus an adult nephew.

This desire to keep women in the wife/mother role was not simply a symptom of the press. When Tangney delivered the address-in-reply, one paper reported her speech after an item dealing with the maiden speech of Dr John Gaha, who called for an increase in Australia's population as a matter of national security. 
It would take two centuries to rectify Australia's population unless they applied themselves to it in an intelligent manner. Women had come into industry and now did not marry until they were 28 , instead of marrying at 18 and having larger families as their mothers did. 'This all sounds incongruous coming from a bachelor,' said Dr. Gaha, 'but the bachelor is the only man game enough to put his feet on the mantelpiece and ponder these things.' (Laughter). (Sydney Morning Herald, September 25, 1943, p. 8).

It was indeed an incongruous statement coming from a man who was not helping to build Australia's population himself, but it clearly placed the onus of protecting the country's future on women, and blamed the population growth decline on women leaving their traditional roles and entering the workplace. The paper also failed to print Dame Enid Lyons's rejoinder to Gaha's comment, which this mother of 12 made in her maiden speech: 'I, like him, have pondered on this subject - not with my feet upon the mantle-piece, but kneedeep in shawls and feeding bottles.' (House of Representatives Debates, September 29, 1943, pp. 182-186)

In 1983 Labor's Ros Kelly became the first sitting federal MP to give birth to a child, but she came in for heavy criticism when she went back to work less than a week after leaving hospital. Liberal MP Bruce Goodluck, who no doubt had a wife at home to look after his five daughters, explained what he would have done if he had been in the same position as Kelly. 'If I had been a woman, I would say to my electorate "I'm going to have a baby. I want to go home and take it easy for a while and find out what it is all about so I can talk about it"' (The Age, August 19, 1983, p. 3). The Age also featured a cartoon of Kelly leaving the baby on a change table and walking out the door, while warning the child not to talk to any strangers while she was gone. Kelly was forced to defend her mothering style, telling The Age that her husband and mother were helping to look after the baby, while she was trying to continue her career. '...I've got a responsibility to my child and myself too, and I think I'll be a much better mother through being happy with the job that I'm doing' (The Age, August 24, 1983, p. 11).

As the century wore on, women politicians found they not only had to deal with pressure to live up to the traditional wife-and-mother roles, but also have their sexual activities, real or imagined, come under scrutiny from political enemies and the media alike. When Democrats leader Cheryl Kernot 


\title{
CONTEMPORARY GENDER ISSUES
}

announced her defection to the Labor Party in 1997, newspaper cartoons used the 'seduction' theme, showing her in bed with Labor leaders Kim Beazley and Gareth Evans (Weekend Australian, October 18-19, 1997, p. .2), or as Juliet on the balcony being serenaded by the same two men (Australian, October 16, 1997, p.3). It must be admitted that the cartoons showed remarkable prescience, as proof of Kernot's very real affair with Evans at that time would emerge five years later. However in 1997 the affair was at best little more than rumour, and the cartoons would prompt commentator Kaz Cooke to ask:

\begin{abstract}
When the Prime Minister was promising Methuselah [Tasmanian Senator Brian] Harradine a chicken in every Tasmanian pot and an end to contraception for anybody over the age of nought ... to get him to vote for flogging off Telstra, did editorialists have Howard wearing leather chaps in a gay bar chatting up the snowy-haired Senator in a sleeveless T-shirt and hiking boots? And when the deal was done, were there any images of the two of them in the cot after a vigorous shagging, sharing a cigar and port? Not bloody likely. That'd be offensive (The Australian Magazine, November 8-9, 1997, p. 73).
\end{abstract}

One month after Kernot's defection announcement, The Sun-Herald reported on a relationship she had with a former student, Tony Sinclair, after the youth had finished school in 1975. The story broke on the day that Kernot was to be formally endorsed as a Labor candidate for the federal seat of Dickson, and Kernot herself later commented that the story had been put up by her political enemies (December 14, 1997, pp. 1,3). 'I am unwilling to accept that it should be part of public life,' Kernot later told the Australian Women's Weekly (April 1998, p.4). Some media commentators, including Terry Sweetman, asked what relevance a long-ended relationship had to with Kernot's ability as a parliamentarian. He continued: '.. if the gossip-millers are so assiduous, you might wonder why the same truth-tellers aren't quite so active when it came to exposing the activities of some of the real sleazebags of politics over the years' (Courier-Mail, December 16, 1997, p . 17).

Liberal MP Don Randall found himself at the centre of almost unanimous criticism when he told Parliament that Kernot had 'the morals of an alley cat on heat' and implied that she and Evans had been having an affair. (Weekend Australian, March 14-15, 1998, p. 1). Much has been made of the view in parliaments that MPs' private lives are strictly off-limits, for fear that 58 PACIFIC JOURNALISM REVIEW 12 (1) 2006 
to break that taboo would mean an open season on the private lives of MPs, party hacks and the journalists themselves. Commentators jumped to Kernot's defence, forgetting that Evans was the other aggrieved party in the incident. It was assumed that as a man, he could look after himself. However when the affair was confirmed in July 2002, the coverage concentrated most heavily on Kernot, who had failed to mention it in her newly-published memoir (Jenkins 2003).

Apart from political and media fascination with her sex life, Kernot also had to deal with the expectation that she remain a good housewife. In January 1998, Kernot was taking part in the ALP national conference while her family was moving house. A removalist's truck ran into and damaged her family's new home, narrowly missing her husband. This prompted a journalist to ask Kernot to justify her absence: 'How come you organised to have your family moved during the national conference?' Kernot replied that the question, and the journalist's treatment of her, was 'disgraceful' (The Australian, January 21,1998, p. 4), but her reaction was immediately labelled by a number of commentators as a 'dummy spit'.

The portrayal of female politicians in a sexual context has not been confined to Kernot. The woman who replaced her as Democrats leader, Meg Lees, was involved in negotiations with Prime Minister John Howard, who saw the Democrats' vote as the only means of having the Goods and Services Tax (GST) legislation passed through Parliament. In a Bill Leak cartoon, Lees was depicted as a bondage mistress, with John Howard, in leather pants, kneeling on the ground and kissing her high-heeled black boots. Lees is portrayed as saying 'So ... now that you've adopted the bargaining position...' (Weekend Australian, May 22-23, 1999, p. 32.) At first glance it appears that Lees was at least portrayed in a position of power, albeit a sexual one. However it must be pointed out that men go to bondage mistresses to pretend at letting women have power over them. Once the money is paid at the end, the game is over. That indeed was what happened in reality - once the GST legislation was passed, the Howard Government refused to entertain any further changes to the legislation, despite approaches from the Democrats. When Labor frontbencher Jenny Macklin complained about the sexist nature of that particular cartoon (and others in general), Leak retaliated by portraying her as a bunny girl serving drinks to three men in suits and saying 'I used to be a Federal MP until I got drawn into the scene by a cartoonist' (Weekend Australian, June 12-13, 1999, p. 28).

PACIFIC JOURNALISM REVIEW 12 (1) 200659 


\section{CONTEMPORARY GENDER ISSUES}

Another unfortunate development that appeared with the start of the new millennium is that female politicians also began using gender stereotyping as a means of attacking other female politicians. When Democrats senator Natasha Stott Despoja decided to run for the leadership of her party in early 2001, a supporter of leadership incumbent Meg Lees attempted to damage Stott Despoja's chances by claiming that ageing male Democrats 'feeding sexual fantasies' were a factor in the challenge. South Australian Democrats leader Sandra Kanck was also quoted as saying: 'There is a resentment from society that we give way to gravity, that our breasts are no longer pert. Our mouths drop and we get crow's feet around our eyes' (The Bulletin, April 3, 2001, pp. 24-27). Stott Despoja responded by arguing that far from giving her an advantage, her relative youth had often been used as a political weapon against her.

This use of the 'gender card' among political rivals rose again in January 2005, when Julia Gillard was considering running for the leadership of the Australian Labor Party. One unnamed Labor MP was quoted as saying that 'the Australian people will not cop a left-wing sheila' (The Australian, January 25,2005, p.11). However the opposition to Gillard's ambitions did not stop at the fact that she was left-wing and female, with her lack of a husband and children also drawing comment. One ABC announcer, Sally Loane, depicted Gillard as a sad spinster when describing a newspaper picture of the leadership hopeful in her kitchen. '... There was something terribly lonely about that room, there wasn't even a flower or a picture or a knife on the bench or bread in plastic or anything ... looked like the kitchen was never lived in' (Quoted in The Australian, January 25, 2005. p. 11). This echoes The Age editorial discussing Edith Cowan's victory in 1921, which referred to the 'dreary' homes that would be left by women seeking their political fortune.

Some commentators criticised this concentration on Gillard's domestic arrangements, with Stewart (2005) writing that Gillard had known what was coming to her. 'From the moment she floated the notion of becoming the first woman to lead the federal Labor Party she was destined to be asked a very different set of questions. Single? Female? Childless? Was this really what Australians wanted in their alternative prime minister?' Duncan (2005) agreed, arguing that the eventual leadership winner, Kim Beazley, had been described solely on the basis of his parliamentary experience, with no mention of his marital status or of his children. 'Ms Gillard is a senior front-bencher and 
industrial lawyer with six years' parliamentary experience and a history of leadership. But she's been appraised almost exclusively on her personal life.'

Former federal Labor minister Susan Ryan criticised her party for going back 30 years to the time when she stood for pre-selection, and opponents claimed that the electorate would not vote for her as a divorced mother of two young children. She went on to be elected six times, with big margins. Ryan argued that concentration on a woman politician's marital status and family life was nothing but 'old-fashioned misogyny'.

If a woman can put herself forward for leadership unencumbered by a husband and children, able to devote herself fully to her work, she gets the Julia treatment. If an aspiring female leader has a spouse and offspring, enemies raise other doubts. Will she be neglecting them? Will her family distract her from the affairs of state? What sort of a man would play second fiddle to a powerful wife? (The Australian, January 26,2005, p. 15).

Gillard also hit back at opponents who claimed that an unmarried, childless woman would not understand issues affecting families, arguing that no politician could claim to have experienced every aspect of life. 'A man doesn't know what it's like to be a woman ... In terms of whether being childless counts in politics, well, someone better explain that to [then NSW Premier] Bob Carr, and whether being single counts in politics, well, someone better explain that to [South Australian Premier] Mike Rann' (The Australian, January 25,2005, p. 11).

\section{Conclusion}

The stories being told about women in politics over the past century may have changed slightly, but the attitudes behind them have not. From the time the first woman set foot in any Australian parliament in 1921 until the present, the expectation has been that female politicians should be wives and mothers. However if a woman with children does take a tilt at politics, she is questioned as to how she will continue to care for her children. At the same time, childless and unmarried men have been able to take the reins of government without being questioned as to their suitability. Layered onto this treatment is the more recently developed perception that female politicians are either swayed by sexual overtures, or use their own sexual wiles, in order to further 


\section{CONTEMPORARY GENDER ISSUES}

their political careers. Where Lyons and Tangney only had to deal with discussion of their dress and appearance with some comment on their family lives, female politicians today have to deal with another set of stories. These stories are of women who have to be wooed and won, or who indeed don't have to be wooed at all, since their charms are for sale. The private life coverage alone raises the argument that journalists need to ask themselves whether this coverage is necessary, while the women's political/professional qualifications and policies are being ignored.

This argument has already been made in the United States, with a call for journalists to portray women as they would the men (Powers et al, 1996). Henderson (1999, p. 159) quotes one female MP as saying that it is trendy to have women and families in politics, but argues that no male MP is asked how they will look after their children, as they have wives. Haines (1992, p. 176) argued in the early 1990s that journalists concentrated on a female politician's family life as a way of reassuring themselves and their readers that the woman was 'normal', ' $\ldots$ that they haven't rocked the boat completely because at some stage in their lives they have rocked the cradle'. As Julia Gillard has discovered more than a decade later, it appears that this need for reassurance is still very real.

\section{References}

Baird, J. (2004). Media tarts: How the Australian press frames female politicians. Melbourne: Scribe Publications.

Braden, M. (1996). Women politicians and the media. Lexington: University Press of Kentucky.

Duncan, J. (2005, January 27). It's not time, Gillard tells nation. Courier-Mail, p. 2.

Gans, H. (1979). Deciding what's news: A study of CBS Evening News, NBC Nightly News, Newsweek and Time. New York: Pantheon Books.

Haines, J. (1992). Suffrage to sufferance: 100 years of women in politics. Sydney: Allen \& Unwin.

Henderson, A. (1999). Getting even: Women MPs on life, power and politics. Sydney: HarperCollinsPublishers.

Jenkins, C. (2002). Private lives, public interest: Did we need to know about the Kernot/Evans affair? Australian Studies in Journalism (12): 48-63.

Lake, M. (1994). Personality, individuality, nationality: Feminist conceptions of citizenship 1902-1940. Australian Feminist Studies 19: 25-38.

Powers, A., S. Serini \& S. Johnson (1996). How gender and ethnicity affected primary coverage. Newspaper Research Journal 17(1-2): 105-112. 
Stewart, C. (2005, January 25). Woman on the verge. The Australian, p. 11.

van Acker, E. (1999). Different voices: Gender and politics in Australia. South Yarra: Macmillan Education Australia.

Dr Cathy Jenkins worked as a radio journalist for 16 years, including five years in the Queensland Parliament Press Gallery. Her research areas include female politicians and the media, and media ethics. She is currently a lecturer in journalism at Griffith University.

c.jenkins@griffith.edu.au

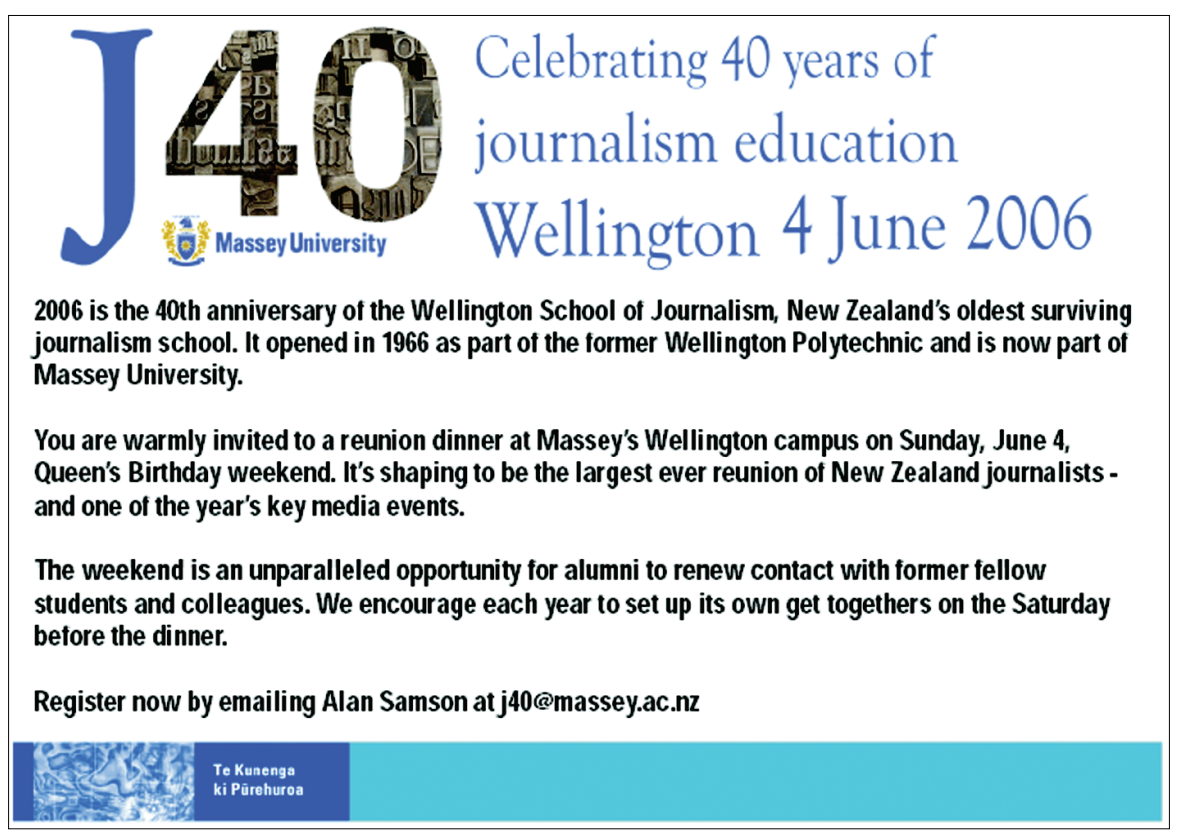

PACIFIC JOURNALISM REVIEW 12 (1) $2006 \mathbf{6 3}$ 